\title{
Challenging the Status Quo in Canada's Education System: The Legacy of Dr. Judy Lupart
}

\author{
Vianne Timmons \\ University of Regina
}

I first met Dr. Judy Lupart when I was a graduate student in 1988. I was so impressed with this dynamic young faculty member that I asked her if she would consider taking me on as a doctoral student. At the time, Dr. Lupart was immersed in setting up the University of Calgary's Centre for Gifted Education and had a full slate of graduate students. Nonetheless, she took the time to listen to my aspirations and facilitated a meeting with Dr. Roy Brown, who became my thesis supervisor.

After I graduated and secured an academic position, Dr. Lupart and I reconnected and began collaborating on a number of research projects. She helped me out a great deal as I assumed from her the editorship of Exceptionality Education Canada and remained a wonderful resource as I edited the journal for almost a decade. Through this process, she became a mentor and an inspiration for me.

Dr. Lupart has had a distinguished career as a researcher, teacher, and leader in the field of education, and some of her most important work has stemmed from her creation of and continuing involvement in Exceptionality Education Canada. Two articles she wrote for the journal, one in 1992 and one in 2002, are of particular note. To me, these articles are a concise representation of what Dr. Lupart has excelled at throughout her academic career-challenging all of us to be analytical and to use research and evidence to identify new ways of approaching education for children with special needs.

In "Toward a Unified System of Education: Where Do We Go from Here?" (1992), Dr. Lupart challenged Canada to "provide equitable and excellent education for all its students" (pp. 5-6). She was a visionary in this way, recognizing that reform was necessary to ensure a more inclusive educational system in Canada. This article is a perfect example of how she carefully researched the educational needs of children who are often underserved or marginalized, and through her work brought attention to the issues facing students, as well as the teachers, leaders, and parents who work with them.

Her subsequent article entitled "Canadian Schools in Transition: Moving from Dual Education Systems to Inclusive Schools" (2002), which she co-authored with Dr. Charles Webber, is a "must read" for educators. This article's thorough and critical analysis of the trends in educating children with special needs is superb. The authors conclude by identifying leadership, staff de- 
velopment, and planning as key elements for successful change, and challenging educators to utilize research and evidence to guide reform. This message is as relevant today as it was then.

In short, by supporting young researchers, setting high standards for Canadian research, and collaborating with others, Dr. Lupart has left an important legacy. Her work with Exceptionality Education Canada is a key part of that legacy, helping create a body of work that will be read by students and academics for many years, and will have a lasting impact on the way Canadians approach educational reform.

\section{References}

Lupart, J. (1992). Toward a unified system of education: Where do we go from here? Exceptionality Education Canada, 2 ( $1 \& 2), 1-7$.

Lupart, J., \& Webber, C. (2002). Canadian schools in transition: Moving from dual education systems to inclusive schools. Exceptionality Education Canada, 12 (2 \& 3), 7-52.

\section{Author's Note}

Correspondence concerning this commentary should be addressed to Vianne Timmons, President and Vice-Chancellor, University of Regina, Ad-Hum 514, 3737 Wascana Parkway, Regina, SK, S4S 0A2. Email: vianne.timmons@uregina.ca 